\title{
Actinomadura nitritigenes sp. nov., Isolated from Experimental Biofilters
}

\author{
ANDRÉ LIPSKI* AND KARLHEINZ ALTENDORF \\ Arbeitsgruppe Mikrobiologie, Fachbereich Biologie/Chemie, Universität Osnabrück, D-49069 Osnabrück, Germany
}

\begin{abstract}
We describe a new species of the genus Actinomadura for four nitrite-producing strains which were isolated from experimental biofilters that had been supplied with ammonia. The whole cells of these strains contain mesodiaminopimelic acid, ribose, madurose, glucose, and galactose. The polar lipids include diphosphatidylglycerol, phosphatidylinositol, and phosphatidylinositol mannosides. The main menaquinone is $\mathrm{MK}-\mathbf{9}\left(\mathrm{H}_{\mathbf{6}}\right)$. The fatty acids include hexadecanoic acid and 10-methyloctadecanoic acid. The guanine-plus-cytosine content of the DNA is 74 mol\%. The fatty acid composition, morphology, and physiological reaction profiles of these strains differentiate them from previously described species. The name proposed for the new species is Actinomadura nitritigenes.
\end{abstract}

Treatment of ammonia-containing waste gases with biofilters leads to the production of nitrite and nitrate, which are products of the nitrification process. Accumulation of these nonvolatile end products and the resulting decrease in the $\mathrm{pH}$ cause a decrease in filter activity. Accumulation of the more toxic product nitrite is often discussed as an effect of disturbed nitrification. A second possible process, which has not been investigated fully, is the reduction of nitrate under aerobic conditions. Detection and characterization of organisms responsible for this reaction should lead to a better understanding of the nitrogen transformations that occur in biofilters, which is essential for future optimization and control of this economical method of waste gas treatment.

During an examination of heterotrophic bacteria isolated from biofilters used for treatment of ammonia-containing waste gases, we found that some strains were able to reduce nitrate to nitrite in a peptone-meat extract medium under aerobic conditions. Four of these strains produced nonfragmenting substrate and aerial mycelia with short spore chains. These characteristics placed the strains in the sporoactinomycete group as defined by Prauser (32). Initially, the genera of this group were defined on the basis of morphological criteria, in contrast to the second broad group of actinomycetes, the nocardioform bacteria (8). Now, most of the sporoactinomycete genera are clearly defined by chemotaxonomic criteria, such as peptidoglycan structure, cell sugar and quinone contents, composition of the polar lipids, and fatty acid profiles. The morphological and chemotaxonomic characteristics of the strains which we isolated were consistent with the definition of the genus Actinomadura (14). The chemotaxonomic, physiological, and morphological properties of these strains led to the proposal of a new species, Actinomadura nitritigenes.

\section{MATERIALS AND METHODS}

Bacterial strains. Strains L20, L34, L46 ${ }^{\mathrm{T}}$ ( $\mathrm{T}=$ type strain), and L81 were isolated from laboratory scale biofilters which contained tree bark compost as the packing material. Strain L81 was isolated from a biofilter supplied with ammonia, and strains L20, L34, and $\mathrm{L}_{4} 6^{\mathrm{T}}$ were isolated from a biofilter supplied with dimethyl disulfide and ammonia. The strains were isolated on DNB agar $(0.03 \mathrm{~g}$ of meat extract per liter, $0.05 \mathrm{~g}$ of peptone from meat per liter [31]) and were subsequently cultivated on oatmeal agar (ISP 3 agar [33]) and GYM agar (ISP 2 agar [33]) which was supplemented with $0.2 \% \mathrm{CaCO}_{3}$. All media were incubated for 2 weeks at $30^{\circ} \mathrm{C}$

Colony characterization. The following media were used for colony charac-

* Corresponding author. Fax: 541/9692870. Electronic mail address: LIPSKI@sfbbio1.biologie.Uni-Osnabrueck.DE. terization (33): oatmeal agar, GYM agar supplemented with $0.2 \% \mathrm{CaCO}_{3}$, inorganic salts-starch agar (ISP 4 agar), glycerol-asparagine agar (ISP 5 agar), peptone-yeast extract-iron agar (ISP 6 agar), and tyrosine agar (ISP 7 agar). Inoculated media were incubated at $30^{\circ} \mathrm{C}$ for 21 days before observations were made. The colors of the mycelia were determined by comparing the mycelia with color chips from the Color Harmony Manual (4). Colonial morphology and pigmentation were also determined by the method of Athalye et al. (2) by using glucose-yeast extract agar.

Physiological tests. Degradation of hypoxarthine, degradation of testosterone, degradation of starch, degradation of L-tyrosine, and degradation of xylan were determined as described by Athalye et al. (2). Degradation of adenine, guanine, xanthine, and casein and hydrolysis of esculin were determined by the method of Gordon et al. (9). Sierra medium (34) was used to test for hydrolysis of Tween 20 and Tween 80 . Nitrate reduction was determined by the method of Gordon and Mihm (10). $\mathrm{H}_{2} \mathrm{~S}$ production was tested on ISP 6 medium with lead acetate strips (Merck, Darmstadt, Germany). Resistance to various inhibitors, antibiotics, and temperatures was determined on GYE agar (2). The basal medium of Stevenson (36) was used for carbon source utilization tests. The media used for carbon source utilization tests were inoculated with spore suspensions, and all other media were inoculated with 1 drop of a preculture grown in GYE broth. All test preparations were incubated at $30^{\circ} \mathrm{C}$, and results were recorded after 7 , 14,21 , and 28 days.

Cultivation for chemotaxonomic analyses. For fatty acid analyses cells were grown in Trypticase soy broth (Becton Dickinson, Heidelberg, Germany) for 15 days at $30^{\circ} \mathrm{C}$, harvested by filtration, and washed twice with deionized water. Actinomadura cremea DSM $43676^{\mathrm{T}}$ was incubated at $37^{\circ} \mathrm{C}$. For all other analyses cells were grown in nutrient broth $(3.0 \mathrm{~g}$ of meat extract [Merck] per liter, $5.0 \mathrm{~g}$ of peptone from meat [Merck] per liter) at $30^{\circ} \mathrm{C}$ for 15 days, harvested by filtration, and washed twice with deionized water. For the quinone, polar lipid, and peptidoglycan analyses the washed cells were lyophilized.

Fatty acid analyses. Saponification, methylation, extraction, and identification of fatty acids were performed as described by Kroppenstedt et al. (15) by using a model 5898A microbial identification system (Hewlett-Packard Co., Palo Alto, Calif.). The identities of fatty acids were verified by performing gas chromatography-mass spectrometry with a Hewlett-Packard model 5890 series II gas chromatograph equipped with a $5 \%$ phenyl methyl silicone capillary column $(0.25$ $\mathrm{mm}$ by $30 \mathrm{~m}$ ) and a model 5972 mass selective detector. Helium was used as the carrier gas, the injection volume was $2 \mu \mathrm{l}$, the injector temperature was $250^{\circ} \mathrm{C}$, the column temperature was increased from 120 to $240^{\circ} \mathrm{C}$ at a rate of $5^{\circ} \mathrm{C} / \mathrm{min}$, and the gas chromatography-mass spectrometry transfer line temperature was $280^{\circ} \mathrm{C}$. Fatty acid methyl esters were separated on the basis of their retention times and were identified by their mass spectra. The positions of unsaturated fatty acid double bonds were determined by analyzing the dimethyl disulfide adducts (28).

Analyses of isoprenoid quinones and polar lipids. Lipids were extracted by using the small-scale integrated procedure of Minnikin et al. (24). Polar lipids were also analyzed by this method by using two-dimensional silica gel thin-layer chromatography. Menaquinones were analyzed by high-performance liquid chromatography (HPLC) by using the method of Kroppenstedt et al. (15).

Analyses of peptidoglycan and cell sugars. We used the method of Becker et al. (3) to determine the diaminopimelic acid isomer in the cell wall. The acyl type of peptidoglycan was determined by the method of Uchida and Aida (39). For the cell sugar analyses we used whole-cell hydrolysates and the method of Lechevalier (17), as modified by Staneck and Roberts (35).

DNA base composition. The guanine-plus-cytosine content of the DNA was determined by workers at the DSM-Deutsche Sammlung von Mikroorganismen und Zellkulturen, Braunschweig, Germany, who used the HPLC method described by Mesbah et al. (21). 
TABLE 1. Colonial characteristics of the isolates on various media

\begin{tabular}{lllll}
\hline Medium & Growth & Reverse color & Aerial mycelium & Soluble pigment \\
\hline ISP 2 agar & Good & Colorless & Brown mahogany (6pn) & None \\
ISP 3 agar & Good & Maple sugar (3ie) & Oyster white (b) & None \\
ISP 4 agar & Good & Clove brown (3ni) & Oyster white (b) & None \\
ISP 5 agar & Good & Colorless & Maple sugar (3ie) & None \\
ISP 6 agar & Moderate & Colorless & Colorless & None \\
ISP 7 agar & Good & Colorless & Brown mahogany (6pn) & None \\
\hline
\end{tabular}

${ }^{a}$ The color codes are the color codes used in the Color Harmony Manual (4).

Microscopy. Cells for light microscopy were grown for 2 weeks at $30^{\circ} \mathrm{C}$ on ISP 2 medium prepared with a slanted cover glass. Mycelia and spore chains were characterized by using an Axioscope instrument (Zeiss, Oberkochen, Germany). The samples used for scanning electron microscopy were 2-week-old mycelia that were grown on oatmeal agar at $30^{\circ} \mathrm{C}$, dehydrated with a graded ethanol series, dried by critical point drying with liquid carbon dioxide, and coated with gold. A Cambridge Stereoscan model 250 microscope was used for scanning electron microscopy.

Comparison with reference strains. Three Actinomadura species were found to be similar to the new isolates in fatty acid composition and physiological reaction profiles when previously published data were examined. Therefore, the type strains of these species, Actinomadura atramentaria DSM 43919, A. cremea DSM 43676, and Actinomadura macra DSM 43962, were included in this study.

\section{RESULTS}

Colony and morphological characterization. Table 1 shows the macroscopic appearance of isolates L20, L34, L46 ${ }^{\mathrm{T}}$, and L81 on various culture media. All four strains exhibited the same growth and colors. Our microscopic examination revealed oval to ellipsoidal spores that had smooth surfaces and were 0.5 to 0.6 by 0.7 to $1.0 \mu \mathrm{m}$. The spore chains were up to seven spores long and straight to hook-like (Fig. 1 and 2).

Chemotaxonomy. The four strains were identical for all of the chemotaxonomic markers which we investigated. The fatty acid profiles revealed that hexadecanoic acid (16:0) and tuberculostearic acid (18:0 10-methyl) were the predominant fatty acids, and 2-hydroxyhexadecanoic acid (16:0 2OH) was a characteristic marker. The fatty acid compositions of the isolates examined are shown in Table 2. meso-Diaminopimelic acid was the diamino acid found. The sugars detected in whole-cell hydrolysates were ribose, madurose, glucose, and galactose. Diphosphatidylglycerol, phosphatidylinositol, and phosphatidylinositol mannosides were the polar lipids and were identified by their chromatographic and staining properties; no nitrogenous compound was found in any polar lipid pattern. The main isoprenoid quinone was $\mathrm{MK}-9\left(\mathrm{H}_{6}\right)$; in addition, there were minor amounts of MK-9 $\left(\mathrm{H}_{8}\right)$ and MK- $9\left(\mathrm{H}_{4}\right)$. The peptidoglycan of the four strains was of the acetyl type. The guanine-plus-cytosine content of strain $246^{\mathrm{T}}$ was $74 \mathrm{~mol} \%$.

Physiology. The physiological reaction profiles of the new isolates and reference strains are shown in Table 3. A remarkable feature of the new isolates was the fact that nitrite accumulated in nutrient broth under aerobic incubation conditions. The final nitrite concentration corresponded to the initial nitrate concentration in nutrient broth when $5 \mathrm{mM} \mathrm{KNO}_{3}$ was added to the medium. The oxygen concentrations of the cultures did not fall below $90 \%$ saturation during incubation as determined with a Clarke type of oxygen electrode.

\section{DISCUSSION}

Identity of the genus. The presence of meso-diaminopimelic acid, the presence of $N$-acetylated muramic acid, the presence of madurose in whole-cell hydrolysates, the presence of a hexahydrogenated menaquinone with nine isoprene units as the main quinone, the lack of any nitrogenous compound in the polar lipids, and the presence of a fatty acid pattern containing 10-methyloctadecanoic acid are consistent with the definition of the genus Actinomadura given by Kroppenstedt and Goodfellow (14). The guanine-plus-cytosine content of isolate $\mathrm{L}^{4} 6^{\mathrm{T}}$ was $74 \mathrm{~mol} \%$; the previously published values for the guanineplus-cytosine contents of members of the genus Actinomadura are 65 to $69 \mathrm{~mol} \%$ (23) and 70 to $78 \mathrm{~mol} \%$ (2). Our strains could be clearly separated from the related genus Microtetraspora by their phospholipid type (type PI, lacking nitrogenous compounds [18]) and from the genus Nocardiopsis by their isoprenoid quinone type. Spore chain length distinguished our strains from the genus Thermomonospora, which is characterized by the presence of single spores.
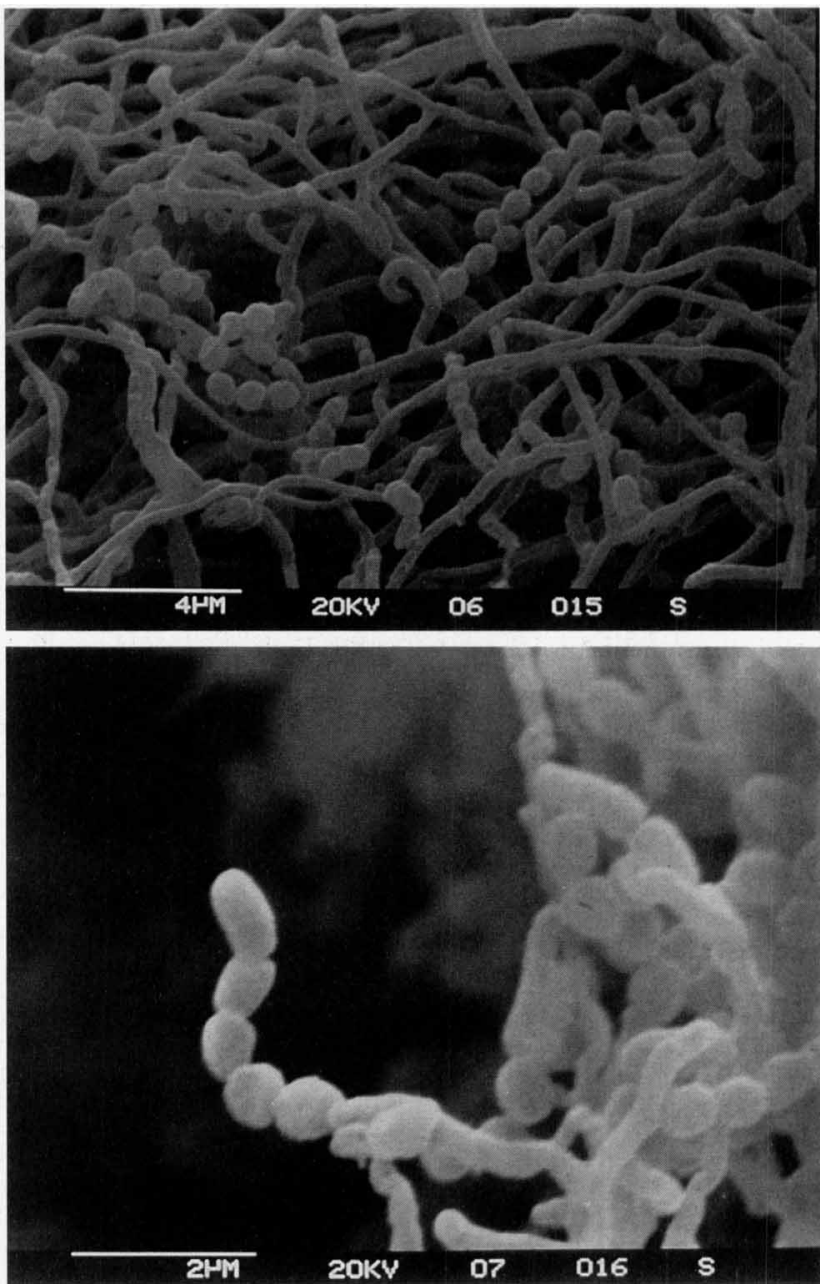

FIG. 1. Scanning electron micrographs of a 2-week-old culture of strain L46 grown on oatmeal agar at $30^{\circ} \mathrm{C}$. 


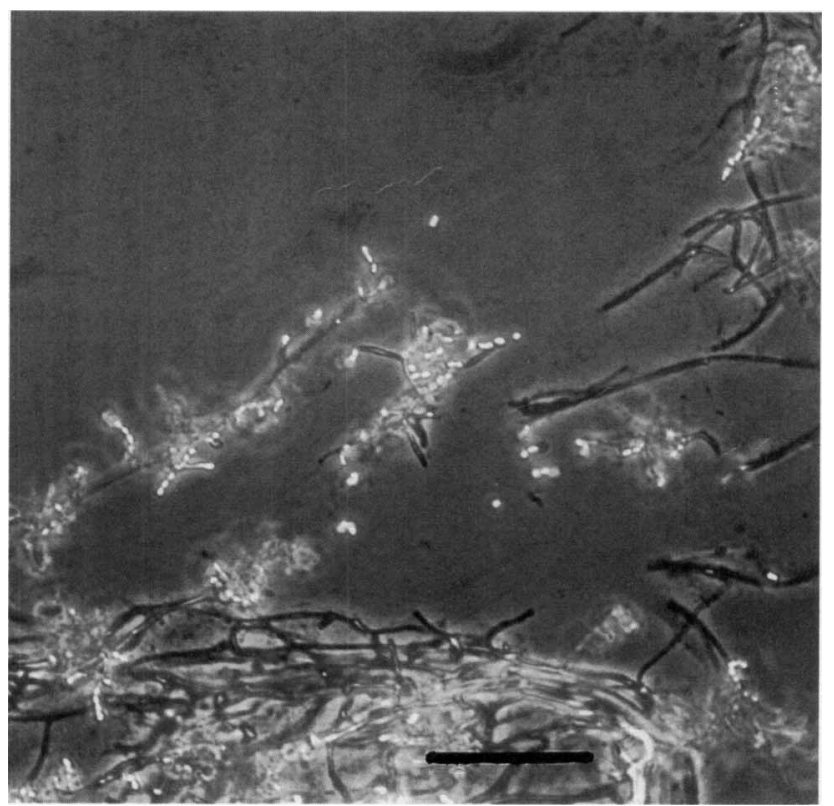

FIG. 2. Phase-contrast micrograph of a 2-week-old culture of strain $\mathrm{L} 46^{\mathrm{T}}$ grown on $\mathrm{GYM}$ agar at $30^{\circ} \mathrm{C}$. Bar $=20 \mu \mathrm{m}$.

Identity of the species. A characteristic marker of our isolates was the presence of 2-hydroxyhexadecanoic acid. According to the results of extensive investigations of Kroppenstedt et al. (15) and other authors $(1,5,25-27)$, this marker has been found previously only in A. atramentaria DSM $43919^{\mathrm{T}}$. However, despite this common marker our isolates can be distinguished from $A$. atramentaria DSM $43919^{\mathrm{T}}$ by some clear differences. The major differences are the amounts of 14:0, 16:0 iso, and 16:0, the presence of 16:0 10-methyl, and the lack of $16: 0$ iso $2 \mathrm{OH}$ in the fatty acid profiles of the new isolates, as shown in Table 2. Although we found quantitative differences for some straight-chain and 10-methyl fatty acids of the refer- ence strains between our data and previously published data, the amount of the diagnostic compound 2-hydroxyhexadecanoic acid which we found was in good agreement with previously published data $(15,25)$. On the basis of the data for this diagnostic marker, the new isolates could not be assigned to any of the reference species included in this study or any species described previously $(1,5,15,25-27)$.

The physiological and morphological properties of the new isolates were compared with the properties of all previously validly described Actinomadura species. Selected morphological data are shown in Table 4. These data show that the new isolates could be separated from all previously described species on the basis of spore chain form and length, spore surface type, aerial and substrate mycelium colors, and the lack of any soluble pigment. These differences confirmed the results of the fatty acid analyses. In addition, we found differences in the physiological properties of the new isolates and most of the previously described species, as follows: $A$. atramentaria is negative for growth on D-xylose, L-arabinose, and sucrose (25), negative for growth on galactose, negative for degradation of hypoxanthine, and positive for degradation of adenine (this study); Actinomadura aurantiaca is negative for degradation of casein, hypoxanthine, and esculin (23); Actinomadura citrea is positive for starch degradation (23), negative for growth in the presence of $0.01 \%$ potassium tellurite, positive for growth in the presence of $5 \% \mathrm{NaCl}$, and positive for growth on maltose and pyruvate (2); Actinomadura coerulea is negative for esculin degradation (23) and positive for degradation of guanine (14); $A$. cremea is positive for growth on maltose, negative for growth on cellobiose, mannose, galactose, and starch, negative for degradation of hypoxanthine, negative for growth at $45^{\circ} \mathrm{C}$, and susceptible to $3 \mu \mathrm{g}$ of neomycin per ml (2; this study); Actinomadura echinospora is negative for nitrate reduction to nitrite and for growth on L-rhamnose $(26,29)$ and negative for growth at $45^{\circ} \mathrm{C}(29)$; Actinomadura fibrosa is positive for growth in the presence of $5 \% \mathrm{NaCl}$, positive for growth on propionate and pyruvate, and negative for nitrate reduction to nitrite (20); Actinomadura hibisca is positive for degradation of adenine and negative for growth at $45^{\circ} \mathrm{C}$ (38); Actinomadura

TABLE 2. Fatty acid profiles of the new isolates and reference strains

\begin{tabular}{|c|c|c|c|c|c|}
\hline \multirow{3}{*}{ Fatty acid ${ }^{a}$} & \multicolumn{5}{|c|}{$\%$ in: } \\
\hline & \multicolumn{2}{|c|}{$\begin{array}{l}\text { Strains } \mathrm{L} 20, \mathrm{~L} 34, \mathrm{~L} 46^{\mathrm{T}} \text {, } \\
\text { and } \mathrm{L} 81\end{array}$} & \multirow[t]{2}{*}{ A. atramentaria DSM $43919^{\mathrm{T}}$} & \multirow[t]{2}{*}{ A. cremea DSM $43676^{\mathrm{T}}$} & \multirow[t]{2}{*}{ A. macra DSM $43862^{7}$} \\
\hline & Mean & Range & & & \\
\hline $12: 0$ & 1.3 & $0.9-1.7$ & & & 2.0 \\
\hline $14: 0$ iso & 0.5 & $0.0-1.3$ & 2.2 & & 1.6 \\
\hline $14: 0$ & 10.9 & $9.3-13.2$ & 3.8 & 1.7 & 19.2 \\
\hline $15: 0$ & 2.0 & $1.5-2.5$ & 5.8 & 3.4 & 2.8 \\
\hline $16: 0$ iso & 2.2 & $1.9-2.8$ & 22.7 & 11.0 & 5.2 \\
\hline $16: 1$ cis 9 & 5.4 & $4.2-6.6$ & & 1.4 & 2.7 \\
\hline $16: 0$ & 35.8 & $33.7-37.4$ & 16.8 & 38.1 & 47.1 \\
\hline 16:0 10-methyl & 2.2 & $2.0-2.4$ & & 1.7 & 1.3 \\
\hline $17: 1$ cis 9 & 0.7 & $0.4-1.0$ & 2.8 & & \\
\hline $16: 0$ iso $2 \mathrm{OH}$ & & & 4.4 & & \\
\hline $17: 0$ & 1.2 & $0.7-1.8$ & 8.6 & 5.9 & 1.6 \\
\hline $16: 02 \mathrm{OH}$ & 4.0 & $3.6-4.4$ & 3.3 & & \\
\hline 17:0 10-methyl & 0.9 & $0.5-1.2$ & 4.9 & 2.2 & \\
\hline $18: 0$ iso & 0.3 & $0.0-0.3$ & 5.1 & 0.9 & \\
\hline $18: 1$ cis 9 & 11.2 & $9.6-13.0$ & 4.7 & 5.5 & 3.0 \\
\hline $18: 0$ & 3.7 & $2.8-4.8$ & 6.0 & 7.0 & 4.7 \\
\hline 18:0 10-methyl & 17.2 & $16.3-18.4$ & 8.9 & 15.6 & 7.6 \\
\hline
\end{tabular}

${ }^{a}$ Examples of abbreviations for fatty acids: 16:0, hexadecanoic acid; 18:0 10-methyl, 10-methyloctadecanoic acid (tuberculosteric acid); $18: 1$ cis 9 , cis-9-octadecenoic acid; 16:0 2OH, 2-hydroxyhexadecanoic acid. 
TABLE 3. Colonial characteristics and physiological reaction profiles of the new isolates and reference strains

\begin{tabular}{|c|c|c|c|c|}
\hline Characteristic & $\begin{array}{l}\text { Strains } \mathrm{L} 20, \mathrm{~L} 34, \\
\mathrm{~L} 46^{\mathrm{T}} \text {, and } \mathrm{L} 81^{a}\end{array}$ & $\begin{array}{c}\text { A. cremea } \\
\text { DSM } 43676^{\mathrm{T}}\end{array}$ & $\begin{array}{l}\text { A. atramentaria } \\
\text { DSM } 43919^{\mathrm{T}}\end{array}$ & A. $\underset{43862^{\mathrm{T}}}{\operatorname{macra}}$ DSM \\
\hline \multicolumn{5}{|l|}{ Colonial characteristics } \\
\hline Aerial mycelium sparse & 0 & + & - & - \\
\hline Aerial mycelium moderate & 0 & - & - & + \\
\hline Aerial mycelium abundant & 100 & - & + & - \\
\hline Colonies white, cream, or yellow & 100 & + & + & + \\
\hline Diffusible pigment brown & 0 & - & + & - \\
\hline Colony elevation crateriform & 100 & + & + & - \\
\hline Colony elevation irregular & 0 & - & - & + \\
\hline Colony margin entire & 0 & + & - & + \\
\hline Colony margin filamentous & 100 & - & + & - \\
\hline \multicolumn{5}{|l|}{ Formation of: } \\
\hline Nitrite from nitrate & 100 & + & + & + \\
\hline $\mathrm{H}_{2} \mathrm{~S}$ & 0 & + & -- & + \\
\hline \multicolumn{5}{|l|}{ Degradation of: } \\
\hline Casein & 100 & + & + & + \\
\hline Esculin & 100 & + & + & -- \\
\hline Hypoxanthine & 100 & - & - & - \\
\hline Starch & 0 & - & - & - \\
\hline Tween 20 & 100 & + & + & + \\
\hline Tween 80 & 100 & + & + & + \\
\hline L-Tyrosine & 50 & + & -- & - \\
\hline Testosterone & 100 & + & + & - \\
\hline Adenine & 0 & - & + & - \\
\hline Guanine & 0 & -- & -- & -- \\
\hline Xanthine & 0 & - & - & - \\
\hline Xylan & 0 & - & - & - \\
\hline \multicolumn{5}{|l|}{ Growth in the presence of: } \\
\hline Adenine $(0.4 \%, \mathrm{wt} / \mathrm{vol})$ & 0 & - & - & - \\
\hline Crystal violet $(0.0001 \%, \mathrm{wt} / \mathrm{vol})$ & 100 & - & + & + \\
\hline Crystal violet $(0.001 \%, \mathrm{wt} / \mathrm{vol})$ & 0 & - & - & - \\
\hline Phenol $(0.01 \%, \mathrm{wt} / \mathrm{vol})$ & 100 & + & + & + \\
\hline Phenol $(0.1 \%, \mathrm{wt} / \mathrm{vol})$ & 0 & - & - & -- \\
\hline Potassium tellurite $(0.001 \%, \mathrm{wt} / \mathrm{vol})$ & 100 & + & + & + \\
\hline Potassium tellurite $(0.005 \%, \mathrm{wt} / \mathrm{vol})$ & 100 & + & + & + \\
\hline Potassium tellurite $(0.01 \%, \mathrm{wt} / \mathrm{vol})$ & 100 & + & + & + \\
\hline Sodium azide $(0.001 \%, \mathrm{wt} / \mathrm{vol})$ & 100 & + & + & + \\
\hline Sodium azide $(0.01 \%, \mathrm{wt} / \mathrm{vol})$ & 50 & - & - & - \\
\hline Sodium azide $(0.02 \%, \mathrm{wt} / \mathrm{vol})$ & 0 & - & - & - \\
\hline Sodium chloride $(3 \%, \mathrm{wt} / \mathrm{vol})$ & 100 & + & + & - \\
\hline Sodium chloride $(5 \%, \mathrm{wt} / \mathrm{vol})$ & 0 & + & - & - \\
\hline Sodium chloride $(7 \%, \mathrm{wt} / \mathrm{vol})$ & 0 & - & - & - \\
\hline Thallous acetate $(0.0001 \%, \mathrm{wt} / \mathrm{vol})$ & 100 & + & + & + \\
\hline Thallous acetate $(0.001 \%, \mathrm{wt} / \mathrm{vol})$ & 75 & - & + & - \\
\hline Thallous acetate $(0.01 \%$, wt $/ \mathrm{vol})$ & 0 & - & - & - \\
\hline Gentamicin $(4 \mu \mathrm{g} / \mathrm{ml})$ & 0 & - & - & - \\
\hline Gentamicin $(16 \mu \mathrm{g} / \mathrm{ml})$ & 0 & - & - & - \\
\hline Streptomycin $(4 \mu \mathrm{g} / \mathrm{ml})$ & 0 & - & - & + \\
\hline Streptomycin $(16 \mu \mathrm{g} / \mathrm{ml})$ & 0 & - & - & + \\
\hline Neomycin $(3 \mu \mathrm{g} / \mathrm{ml})$ & 100 & - & + & + \\
\hline Neomycin $(10 \mu \mathrm{g} / \mathrm{ml})$ & 50 & - & - & - \\
\hline \multicolumn{5}{|c|}{ Growth on the following compounds as sole carbon sources $(1 \%, \mathrm{wt} / \mathrm{vol})$} \\
\hline Glucose & 100 & + & + & - \\
\hline Arabinose & 100 & + & - & - \\
\hline Cellobiose & 100 & - & + & - \\
\hline Fructose & 100 & + & + & - \\
\hline Galactose & 100 & - & - & + \\
\hline Glycerol & 100 & + & + & + \\
\hline Lactose & 0 & - & + & - \\
\hline Maltose & 0 & + & - & - \\
\hline Mannose & 100 & - & + & - \\
\hline Rhamnose & 100 & + & + & - \\
\hline Starch & 100 & - & - & - \\
\hline Sucrose & 100 & + & - & + \\
\hline Trehalose & 100 & + & + & - \\
\hline Xylose & 100 & + & - & - \\
\hline
\end{tabular}


TABLE 3-Continued

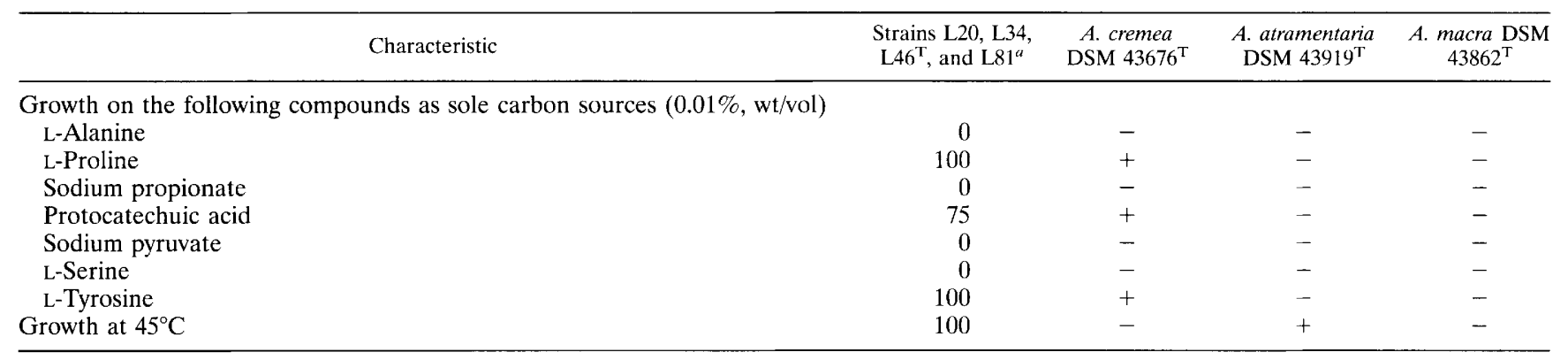

${ }^{a}$ The values are the percentages of positive strains. Strain $\mathrm{L} 46^{\mathrm{T}}$ was negative for degradation of $\mathrm{L}$-tyrosine, negative for growth in the presence of $0.01 \%$ sodium azide and $0.001 \%$ thallous acetate, resistant to $10 \mu \mathrm{g}$ of neomycin per $\mathrm{ml}$, and positive for growth on protocatechuic acid.

kijaniata is positive for growth on maltose, positive for hydrolysis of adenine, xanthine, xylan, and starch, resistant to gentamicin and streptomycin (11), and negative for degradation of testosterone (23); Actinomadura libanotica is positive for growth on maltose, positive for hydrolysis of starch, negative for degradation of casein and hypoxanthine, negative for growth at $45^{\circ} \mathrm{C}$ and for growth on mannose, fructose, and glycerol (22), positive for growth on L-alanine and propionate, positive for growth in the presence of $0.001 \%$ crystal violet, and susceptible to $3 \mu \mathrm{g}$ neomycin per $\mathrm{ml}(2)$; Actinomadura livida is negative for degradation of hypoxanthine and positive for degradation of guanine (14); Actinomadura luteofluorescens is positive for starch degradation, positive for growth on lactose, maltose, L-alanine, pyruvate, and L-serine, negative for growth at $45^{\circ} \mathrm{C}$, and resistant to $3 \mu \mathrm{g}$ of gentamicin per $\mathrm{ml}$ and $16 \mu \mathrm{g}$ of streptomycin per $\mathrm{ml}(2) ; A$. macra is positive for $\mathrm{H}_{2} \mathrm{~S}$ formation, negative for growth at $45^{\circ} \mathrm{C}$, negative for growth on arabinose, rhamnose, fructose, and mannose (12), negative for degradation of esculin and testosterone, and resistant to $16 \mu \mathrm{g}$ of streptomycin per ml (this study); Actinomadura madurae is

TABLE 4. Morphological characteristics of strain $\mathrm{L} 46^{\mathrm{T}}$ and previously described Actinomadura species

\begin{tabular}{|c|c|c|c|c|c|c|c|c|c|c|c|c|c|c|c|c|c|}
\hline \multirow{2}{*}{ Species or strain } & \multicolumn{2}{|c|}{ Spore chains } & \multirow{2}{*}{$\begin{array}{c}\text { Spore } \\
\text { surface }^{a}\end{array}$} & \multirow{2}{*}{$\begin{array}{l}\text { Interspore } \\
\text { pads }\end{array}$} & \multicolumn{4}{|c|}{$\begin{array}{l}\text { Color of aerial } \\
\text { mycelium on }{ }^{b} \text { : }\end{array}$} & \multicolumn{4}{|c|}{$\begin{array}{l}\text { Color of substrate mycelium } \\
\qquad \mathrm{on}^{b}:\end{array}$} & \multicolumn{4}{|c|}{$\begin{array}{c}\text { Color of soluble pigment } \\
\text { on }^{b} \text { : }\end{array}$} & \multirow{2}{*}{ Reference(s) } \\
\hline & Form $^{c}$ & $\begin{array}{l}\text { No. of } \\
\text { spores }\end{array}$ & & & $\begin{array}{l}\text { ISP } 2 \\
\text { agar }\end{array}$ & $\begin{array}{l}\text { ISP } 3 \\
\text { agar }\end{array}$ & $\begin{array}{c}\text { ISP } 4 \\
\text { agar }\end{array}$ & $\begin{array}{l}\text { ISP } 5 \\
\text { agar }\end{array}$ & $\begin{array}{c}\text { ISP } 2 \\
\text { agar }\end{array}$ & $\begin{array}{l}\text { ISP } 3 \\
\text { agar }\end{array}$ & $\begin{array}{l}\text { ISP } 4 \\
\text { agar }\end{array}$ & $\begin{array}{l}\text { ISP } 5 \\
\text { agar }\end{array}$ & $\begin{array}{l}\text { ISP } 2 \\
\text { agar }\end{array}$ & $\begin{array}{c}\text { ISP } 3 \\
\text { agar }\end{array}$ & $\begin{array}{l}\text { ISP } 4 \\
\text { agar }\end{array}$ & $\begin{array}{l}\text { ISP } 5 \\
\text { agar }\end{array}$ & \\
\hline A. atramentaria & str & $3-5$ & sm & $-{ }^{d}$ & wh & wh & wh & wh & br & $\mathrm{cl}$ & $\mathrm{cl}$ & br & br & - & - & br & 25 \\
\hline A. aurantiaca & ho-sp & $4-8$ & wa & + & wh & cr-pi & wh & & ye-br & ye & cr-or & & - & - & - & & 23 \\
\hline A. carminata & psp & $6-14$ & $\mathrm{sm}$ & - & & pi & & & & re-vi & & & & - & & & 7 \\
\hline A. citrea & ho & $3-9$ & wa & - & - & $\begin{array}{l}\text { wh- } \\
\text { bl }\end{array}$ & ye-bl & & ye-bl & ye & ye-br & & - & ye & ye & & 23 \\
\hline A. coerulea & ho-sp & & wa & - & - & pi-bl & bl & & br & $\mathrm{cl}$ & $\mathrm{cl}$ & & - & - & - & & 23 \\
\hline A. cremea & ho-sp & & wa & - & wh & wh- & $\mathrm{cr}-\mathrm{pi}$ & & br & $\mathrm{cl}$ & $\mathrm{cl}$ & & - & - & - & & 23 \\
\hline A. echinospora & & 2 & spi & - & & ye-pi & & & br & ye-or & $\operatorname{tr}$ & $\operatorname{tr}$ & ye-br & ye-br & & & 14,29 \\
\hline A. fibrosa & - & - & - & - & wh & pi & pi & - & br & or & br & or & br & - & - & - & 20 \\
\hline A. fulvescens & $\mathrm{sp}$ & & sm & - & & - & - & - & & $\mathrm{cl}$ & & ye & & & & & 37 \\
\hline A. hibisca & str & $10-50$ & $\mathrm{sm}$ & - & wh & & & wh & re & & & cl-pi & re & & & ye-pi & 38 \\
\hline A. kijaniata & $\mathrm{sp}$ & $>10$ & $\mathrm{sm}$ & - & wh & wh & - & - & $\mathrm{gr}$ & $\mathrm{gr}$ & $\mathrm{gr}$ & $\mathrm{gr}$ & - & - & gr & gy-br & 11 \\
\hline A. libanotica & ho & $5-12$ & wa & + & pi & $\begin{array}{l}\text { wh- } \\
\text { pi }\end{array}$ & & & ye-br & ye-br & & & - & - & & & 22 \\
\hline A. livida & ho-sp & & irr & - & - & $\operatorname{tr}$ & $\operatorname{tr}$ & & br & gy-br & ye-br & & - & vi & vi & & 23 \\
\hline A. luteofluorescens & ho & & wa & - & wh-ye & ye-bl & $\operatorname{tr}$ & & ye & ye-gr & or-br & & ye & ye-gr & ye & & 23 \\
\hline A. macra & str-ho & $4-15$ & $\mathrm{sm}$ & - & wh-gy & cr-pi & - & $\mathrm{cr}$ & bk & cr-pi & $\mathrm{cl}$ & $\mathrm{cr}$ & br & - & - & - & 12 \\
\hline A. madurae & ho-sp & $3-12$ & wa & - & - & $\operatorname{tr}$ & - & & pi-br & $\mathrm{cl}$ & wh-gy & & - & - & - & & 23 \\
\hline A. oligospora & ho & $10-50$ & $\mathrm{sm}$ & - & - & wh & wh & - & gy & gy & gy & gy & br & - & - & - & 19 \\
\hline A. pelletieri & ho-sp & $2-6$ & wa & - & $\operatorname{tr}$ & - & - & & pi-br & pi-br & - & & - & - & - & & 23 \\
\hline A. rubra & $\mathrm{sp}$ & $2-20$ & spi & - & & $\mathrm{gr}-\mathrm{bl}$ & & & & or & & & & - & & & 14 \\
\hline A. rugatobispora & & 2 & ru & - & & & & & & & & & & & & & 26 \\
\hline A. spadix & psp & $5-10$ & $\mathrm{sm}$ & - & & & & & br & gy-br & gy-br & gy-br & br & gy-br & & gy-br & 30 \\
\hline A. umbrina & & & $\mathrm{sm}$ & & & wh & - & - & & $\mathrm{cl}$ & - & $\operatorname{tr}$ & & pi-br & - & & 6 \\
\hline A. verrucosospora & ho & $5-15$ & wa & - & & bl & gy & & ye & $\operatorname{tr}$ & pi-or & pi-or & - & - & - & - & 30 \\
\hline A. vinacea & str & & irr & - & - & - & wh-gy & & br-re & pi-re & $\mathrm{cl}$ & & re & - & pi & & 23 \\
\hline A. viridis & str & 4 & $\mathrm{sm}$ & - & & & & & & & & & & & & & 27 \\
\hline A. yumanensis & ho & $\sim 20$ & $\mathrm{sm}$ & - & - & wh & wh & wh & ye-br & gy-ye & $\mathrm{cl}$ & ye & or & - & - & ye & 16 \\
\hline $\mathrm{L} 46^{\mathrm{T}}$ & str-ho & $2-7$ & $\mathrm{sm}$ & - & br & wh & wh & br & $\mathrm{cl}$ & br & br & $\mathrm{cl}$ & - & - & - & - & \\
\hline
\end{tabular}

${ }^{a}$ sm, smooth; wa, warty; spi, spiny; irr, irregular; ru, rugose.

${ }^{b}$ bk, black; bl, blue; br, brown; cl, colorless; cr, cream; gr, green; gy, gray; or, orange; pi, pink; re, red; vi, violet; wh, white; ye, yellow; tr, trace.

${ }^{c}$ str, straight; ho, hooked; sp, spiral; psp, pseudosporangia.

${ }^{d}-$, absent; + , present. 
positive for growth in the presence of $5 \% \mathrm{NaCl}$, positive for growth on maltose, and positive for starch hydrolysis (2); $A c$ tinomadura oligospora is negative for growth on galactose, sucrose, arabinose, mannose, trehalose, and rhamnose, negative for nitrate reduction to nitrite, and negative for testosterone degradation (19); Actinomadura pelletieri is negative for testosterone degradation, negative for growth on arabinose, glycerol, L-rhamnose, starch, sucrose, trehalose, and xylose, susceptible to $3 \mu \mathrm{g}$ of neomycin per $\mathrm{ml}$, and positive for growth in the presence of $0.001 \%$ crystal violet (2); Actinomadura rugatobispora is positive for starch hydrolysis and negative for growth on D-xylose (26); Actinomadura spadix is positive for starch hydrolysis (23) and negative for degradation of testosterone and hypoxanthine (14); Actinomadura verrucosospora is negative for growth at $45^{\circ} \mathrm{C}$, negative for nitrate reduction to nitrite (30), and positive for guanine hydrolysis (20); Actinomadura vinacea is negative for nitrate reduction to nitrite and negative for degradation of testosterone and hypoxanthine (23); Actinomadura viridis is positive for growth in the presence of $5 \%$ $\mathrm{NaCl}$ and negative for nitrate reduction to nitrite (27); and Actinomadura yumanensis is positive for growth on maltose, pyruvate, and propionate, positive for degradation of starch and xanthin, and negative for growth on arabinose, L-rhamnose, and D-xylose (16).

Recently, the conclusions based on chemotaxonomic, physiological, and morphological data were confirmed by the sequence of 450 nucleotides from the $5^{\prime}$ end of the $16 \mathrm{~S}$ rRNA of isolate $\mathrm{L}^{4} 6^{\mathrm{T}}$ (13). Comparisons with the sequences of $A$. $\mathrm{ma}$ durae DSM $43067^{\mathrm{T}}, A$. atramentaria DSM $43919^{\mathrm{T}}, A$. verrucosospora DSM $43358^{\mathrm{T}}$, A. luteofluorescens DSM $40398^{\mathrm{T}}$, and Thermomonospora fermosensis DSM $43997^{\mathrm{T}}$. resulted in levels of homology of less than $96 \%$. Thus, strain $\mathrm{L} 46^{\mathrm{T}}$ could not be assigned to one of these species. Assignment to the genus Actinomadura was confirmed by the sequence data (12a).

Description of Actinomadura nitritigenes. We propose the name Actinomadura nitritigenes (ni.tri.i'ge.nes. L. n. nitritum, nitrite; Gr. v. suff.-genes, producing; L. adj. nitritigenes, nitrite producing) for isolates $\mathrm{L} 20, \mathrm{~L} 34, \mathrm{~L} 46^{\mathrm{T}}$, and $\mathrm{L} 81$. The type strain is strain L46. A. nitritigenes forms branching vegetative and aerial mycelia. Spores are produced in straight or hooklike chains that are up to seven spores long. The spore surface is smooth. The aerial mycelium is white. No soluble pigment is produced. Degrades casein, esculin, Tween 20 , Tween 80 , hypoxanthine, and testosterone. Does not degrade adenine, guanine, xanthine, and xylan and does not form $\mathrm{H}_{2} \mathrm{~S}$. Nitrate is reduced to nitrite even under aerobic incubation conditions. Grows on glucose, arabinose, cellobiose, fructose, galactose, glycerol, mannose, rhamnose, starch, sucrose, trehalose, xylose, L-proline, and L-tyrosine. Does not grow on lactose, maltose, L-alanine, propionate, pyruvate, and L-serine. Grows at $45^{\circ} \mathrm{C}$. Contains meso-diaminopimelic acid, an acetyl type of peptidoglycan, and madurose. Phospholipid type PI. MK$9\left(\mathrm{H}_{6}\right)$ is the major menaquinone. The major fatty acids are hexadecanoic acid and tuberculostearic acid; minor amounts of 2-hydroxyhexadecanoic acid occur. Aerobic and mesophilic. All strains were isolated from experimental biofilters which were filled with tree bark compost as filter material and supplied with ammonia. Isolate L46 ${ }^{\mathrm{T}}\left(=\mathrm{DSM} 44137^{\mathrm{T}}\right.$ ) has been deposited in the DSM-Deutsche Sammlung von Mikroorganismen und Zellkulturen $\mathrm{GmbH}$, Braunschweig, Germany.

\section{ACKNOWLEDGMENTS}

We thank Rainer M. Kroppenstedt and Stefan Klatte, DSM-Deutsche Sammlung von Mikroorganismen und Zellkulturen GmbH, Braunschweig, Germany, for analyzing the fatty acid methyl ester extracts with the model $5898 \mathrm{~A}$ microbial identification system and for analyzing the quinone extracts. We thank also Frank Niemeyer, Universität Osnabrück, for his help in obtaining the scanning electron micrographs.

\section{REFERENCES}

1. Agre, N. S., T. N. Efimova, and L. N. Guzeva. 1975. Heterogeneity of the genus Actinomadura Lechevalier a. Lechevalier. Mikrobiologiya 44:253-257.

2. Athalye, M., M. Goodfellow, J. Lacey, and R. P. White. 1985 . Numerical classification of Actinomadura and Nocardiopsis. Int. J. Syst. Bacteriol. 35: 86-98.

3. Becker, B., M. P. Lechevalier, R. E. Gordon, and H. A. Lechevalier. 1964. Rapid differentiation between Nocardia and Streptomyces by paper chromatography of whole-cell hydrolysates. Appl. Microbiol. 12:421-423.

4. Container Corporation of America. 1958. Color harmony manual, 4th ed. Container Corporation of America, Chicago.

5. Fischer, A., R. M. Kroppenstedt, and E. Stackebrandt. 1983. Moleculargenetic and chemotaxonomic studies on Actinomadura and Nocardiopsis. J. Gen. Microbiol. 129:3433-3446.

6. Galatenko, O. A., L. P. Terekhova, and T. P. Preobrazhenskaya. 1981. New Actinomadura species isolated from Turkmen soil samples and their antagonistic properties. Antibiotiki (Moscow) 26:803-807.

7. Gauze, G. F. M. A. Sveshnikova, R. S. Ukholina, G. V. Gavrilina, V. A. Filicheva, and E. G. Gladkikh. 1973. Production of antitumor antibiotic carminomycin by Actinomadura carminata sp. nov. Antibiotiki (Moscow) 8:675-678.

8. Goodfellow, M., and T. Pirouz. 1982. Numerical classification of sporoactinomycetes containing meso-diaminopimelic acid in the cell wall. J. Gen. Microbiol. 128:503-527.

9. Gordon, R. E., D. A. Barnett, J. E. Handerhan, and C. H.-N. Pang. 1974. Nocardia coeliaca, Nocardia autotrophica, and the nocardin strain. Int. J. Syst. Bacteriol, 24:54-63.

10. Gordon, R. E., and J. M. Mihm. 1957. A comparative study of some strains received as nocardiae. J. Bacteriol. 73:15-27.

11. Horan, A. C., and B. C. Brodsky. 1982. A novel antibiotic-producing Actinomadura, Actinomadura kijaniata sp. nov. Int. J. Syst. Bacteriol. 32:195-200.

12. Huang, L. H. 1980. Actinomadura macra sp. nov., the producer of antibiotics CP-47,433 and CP-47,434. Int. J. Syst. Bacteriol. 30:565-568.

12a.Koch, C., and F. A. Rainey. Personal communication.

13. Koch, C., F. A. Rainey, and E. Stackebrandt. Unpublished data.

14. Kroppenstedt, R. M., and M. Goodfellow. 1992. The family Thermomonosporaceae, p. 1085-1114. In A. Balows, H. G. Trüper, and M. Dworkin (ed.). The prokaryotes. Springer-Verlag, New York

15. Kroppenstedt, R. M., E. Stackebrandt, and M. Goodfellow. 1990. Taxonomic revision of the actinomycete genera Actinomadura and Microtetraspora. Syst. Appl. Microbiol. 13:148-160.

16. Labeda, D. P., R. T. Testa, M. P. Lechevalier, and H. A. Lechevalier. 1985. Actinomadura yumanensis sp. nov. Int. J. Syst. Bacteriol, 35:333-336.

17. Lechevalier, M. P. 1968. Identification of aerobic actinomycetes of clinical importance. J. Lab. Clin. Med. 71:934-944.

18. Lechevalier, M. P., C. De Bievre, and H. Lechevalier. 1977. Chemotaxonomy of aerobic actinomycetes: phospholipid composition. Biochem. Syst. Ecol. 5:249-260.

19. Mertz, F. P., and R. C. Yao. 1986. Actinomadura oligospora sp. nov., the producer of a new polyether antibiotic. Int. J. Syst. Bacteriol. 36:179-182.

20. Mertz, F. P., and R. C. Yao. 1990. Actinomadura fibrosa sp. nov. isolated from soil. Int. J. Syst. Bacteriol. 40:28-33.

21. Mesbah, M., U. Premachandran, and W. B. Whitman. 1989. Precise measurement of the $\mathrm{G}+\mathrm{C}$ content of deoxyribonucleic acid by high-performance liquid chromatography. Int. J. Syst. Bacteriol. 39:159-167.

22. Meyer, J. 1979. New species of the genus Actinomadura. Z. Allg. Mikrobiol. 19:37-44.

23. Meyer, J. 1989. Genus Actinomadura, p. 2511-2526. In S. T. Williams, M. E. Sharpe, and J. G. Holt (ed.), Bergey's manual of systematic bacteriology, vol. 4. Williams \& Wilkins, Baltimore.

24. Minnikin, D. E., A. G. O'Donnell, M. Goodfellow, G. Alderson, M. Athalye, A. Schaal, and J. H. Parlett. 1984. An integrated procedure for the extraction of bacterial isoprenoid quinones and polar lipids. J. Microbiol. Methods 2:233-241.

25. Miyadoh, S., S. Amano, H. Tohyama, and T. Shomura. 1987. Actinomadura atramentaria, a new species of the Actinomycetales. Int. J. Syst. Bacteriol. 37:342-346

26. Miyadoh, S., S. Amano, H. Tohyama, and T. Shomura. 1990. A taxonomic review of the genus Microbispora and a proposal to transfer two species to the genus Actinomadura and to combine ten species into Microbispora rosea. J. Gen. Microbiol. 136:1905-1913.

27. Miyadoh, S., H. Anzai, S. Amano, and T. Shomura. 1989. Actinomadura malachitica and Microtetraspora viridis are synonyms and should be transferred as Actinomadura viridis comb. nov. Int. J. Syst. Bacteriol. 39:152-158.

28. Nichols, P. D., J. B. Guckert, and D. C. White. 1986, Determination of monounsaturated fatty acid double-bond position and geometry for microbial monocultures and complex consortia by capillary GC-MS of their dimethyl disulphide adducts. J. Microbiol. Methods 5:49-55. 
29. Nonomura, H., and Y. Ohara. 1971. Distribution of actinomycetes in soil. IX. New species of the genera Microbispora and Microtetraspora, and their isolation method. J. Ferment. Technol. 49:887-894.

30. Nonomura, H., and Y. Ohara. 1971. Distribution of actinomycetes in soil. XI Some new species of the genus Actinomadura Lechevalier $e$ t al. J. Ferment. Technol. 49:904-912.

31. Olsen, R. A., and L. R. Bakken. 1987. Viability of soil bacteria: optimization of plate-counting technique and comparison between total counts and plate counts within different size groups. Microb. Ecol. 13:59-74.

32. Prauser, H. 1970. Characters and genera arrangement in the Actinomycetales, p. 407-418. In H. Prauser (ed.), The Actinomycetales. Gustav Fischer, Jena, Germany.

33. Shirling, E. B., and D. Gottlieb. 1966. Methods for characterization of Streptomyces species. Int. J. Syst. Bacteriol, 16:313-340.

34. Sierra, G. 1957. A simple method for the detection of lipolytic activity of micro-organisms and some observations on the influence of the contact between cells and fatty substrates. Antonie Leeuwenhoek 23:15-22.

35. Staneck, J. L., and G. D. Roberts. 1974. Simplified approach to identification of aerobic actinomycetes by thin-layer chromatography. Appl. Microbiol. 28:226-231.

36. Stevenson, I. L. 1967. Utilization of aromatic hydrocarbons by Arthrobacter spp. Can. J. Microbiol. 13:205-211.

37. Terekhova, L. P., O. A. Galatenko, and T. P. Preobrazhenskaya. 1982. Actinomadura fulvescens sp. nov. and Actinomadura turkmeniaca sp. nov. and their antagonistic properties. Antibiotiki (Moscow) 27:87-92.

38. Tomita, K., M. Nishio, K. Saitoh, H. Yamamoto, Y. Hoshino, H. Ohkuma, M Konishi, T. Miyaki, and T. Oki. 1990. Pradimicins A, B and C: new antifungal antibiotics. I. Taxonomy, production, isolation and physico-chemical properties. J. Antibiot. 43:755-762.

39. Uchida, K., and K. Aida. 1977. Acyl type of bacterial cell wall: its simple identification by colorimetric method. J. Gen. Appl. Microbiol. 23:249-260. 